\title{
Analisis Kesulitan Belajar Muatan Matematika Kelas IV SD Tahfidzul Qur'an Darul Abror
}

\author{
Unais Mabruroh*1, Diah Sunarsih ${ }^{2}$, Atikah Mumpuni ${ }^{3}$ \\ ${ }^{1,2,3}$ Program Studi Pendidikan Guru Sekolah Dasar, Fakultas Keguruan dan Ilmu Pendidikan, \\ Universitas Muhadi Setiabudi Brebes, Indonesia \\ e-mail:*1] unaismabruroh@gmail.com, ${ }^{2}$ diahsunarsih@umus.ac.id, ${ }^{3}$ atikahmumpuni@umus.ac.id
}

\begin{abstract}
ABSTRAK
Penelitian ini dilakukan pada peserta didik kelas IV SD Tahfidzul Qur'an Darul Abror yang mengalami kesulitan pembelajaran matematika. Penelitian ini bertujuan untuk mengetahui jenis dan faktor penyebab kesulitan belajar matematika pada materi bangun datar persegi dan persegi panjang. Penelitian ini menggunakan penelitian kualitatif dengan pendekatan deskriptif. Pengumpulan data menggunakan hasil tes, observasi partisipatif, wawancara, dan dokumentasi. Teknik analisis data menggunakan pengumpulan data, reduksi data, penyajian data dan penarikan kesimpulan. Berdasarkan hasil penelitian disimpulkan bahwa jenis kesulitan belajar muatan matematika materi bangun persegi dan persegi panjang yang dialami oleh peserta didik kelas IV yaitu: a) peserta didik belum memahami sifat-sifat bangun datar persegi dan persegi panjang, b) kesulitan menentukan rumus untuk menyelesaikan suatu masalah, c) kelemahan dalam menghitung, d) kesulitan bahasa dan membaca. Faktor penyebab kesulitan belajar terdiri dari faktor internal dan faktor eksternal. Faktor internal adalah faktor yang berasal dari diri peserta didik, meliputi kesehatan fisik dan sikap peserta didik Faktor eksternal adalah faktor yang berasal dari luar diri peserta didik, meliputi sikap guru dan alat pembelajaran. Saran dalam penelitian ini adalah pembelajaran matematika perlu pengulangan dan memperbanyak frekuensi latihan soal, sehingga peserta didik dapat memahami konsep matematika.
\end{abstract}

Kata kunci: kesulitan belajar, matematika, faktor internal, faktor eksternal

\begin{abstract}
This study was conducted in class IV students of SD Tahfidzul Qur'an Darul Abror who have difficulty learning mathematics. The study aims to determine the types and causes of learning math difficulties in the rectangular and rectangular flat build material. The study used qualitative research with a descriptive approach. Data collection using test results, participatory observation, interviews, and documentation. Data analysis techniques using data collection, data reduction, data presentation and withdrawal of conclusions. Based on the results of the study concluded that the type of difficulty learning the content of the mathematics and rectangular material that experienced by the class IV students are: a) learners have not understood the properties of the flat build square and rectangular, b) difficulty determining the formula to solve a problem, c) weakness in counting, d) language difficulties and reading. The factors cause learning difficulties consist of internal factors and external factors. Internal factors are factors that come from students, including physical health and the attitude of learners external factors are factors that come from outside students, including teacher attitudes and learning tools. The advice in this study is that math learning needs repetition and multiply the frequency of practice, so that learners can understand the concept of mathematics.
\end{abstract}

Keywords: difficulty learning, mathematics, internal factors, external factors

\section{PENDAHULUAN}

Matematika merupakan muatan pelajaran yang diajarkan di semua jenjang pendidikan. Tujuan pembelajaran matematika di sekolah adalah untuk membekali peserta didik agar dapat hidup bermasyarakat dan dapat melanjutkan pendidikan ke jenjang yang lebih tinggi serta peserta didik dapat menerapkannnya dalam kehidupan sehari-hari [1]. Matematika menjadi syarat yang harus ditempuh oleh peserta didik untuk melanjutkan pendidikan. 
Dalam kegiatan pembelajaran di sekolah, seorang guru dihadapkan oleh beberapa karakter peserta didik. Ada peserta didik yang dapat menerima kegiatan belajar dengan baik dan lancar. Akan tetapi, ada peserta didik yang mengalami kesulitan dalam belajar, khususnya dalam muatan matematika. Kesulitan belajar merupakan kurang berhasilnya siswa dalam menguasai konsep, prinsip, atau algoritma penyelesaian masalah, walaupun telah beruasaha mempelajarinya [2]. Kesulitan belajar yang dialami peserta didik akan berdampak pada prestasi belajar, karena untuk memperoleh prestasi belajar yang baik diperlukan usaha yang baik pula yang dilakukan oleh peserta didik dalam belajar. Kesulitan belajar yang dialami peserta didik disebabkan karena faktor internal dan faktor eksternal [3].

Berdasarkan wawancara dengan guru masalah yang dihadapi oleh kelas IV SD Tahfidzul Qur'an Darul Abror adalah sebagian besar peserta didik mengalami kesulitan pada pembelajaran matematika. Kesulitan belajar tersebut mengakibatkan hasil belajar rendah. Hasil belajar matematika rendah karena peserta didik beranggapan bahwa matematika adalah muatan pembelajaran yang sulit, membosankan dan menakutkan, sehingga peserta didik tidak menyukai matematika. Beberapa peserta didik yang kurang memahami konsep bangun datar, terutama dalam mengaplikasikan rumus. Kemampuan berhitung peserta didik juga masih kurang. Didalam menghitung peserta didik masih mengalami kesalahan pada proses dan hasil hitungan.

Permasalahan pembelajaran matematika tersebut didukung penelitian terdahulu yang hasilnya menunjukan bahwa kesulitan belajar yang dialami peserta didik antara lain, peserta didik belum mampu memahami konsep penyelesaian luas gabungan bangun datar, kesulitan dalam menentukan rumus, dan kesulitan dalam memahami operasi hitung perkalian. Faktor penyebab kesulitan peserta didik antara lain, faktor yang berasal dari dalam diri peserta didik yaitu kurangnya ketertarikan peserta didik dalam belajar matematika, dan faktor luar yaitu guru tidak tersenyum kepada peserta didik [4].

\section{METODOLOGI PENELITIAN}

Penelitian ini menggunakan pendekatan penelitian kualitatif. Penelitian ini difokuskan pada kesulitan belajar matematika kelas IV SD Tahfidzul Qur'an Darul Abror. Sumber data dalam penelitian ini adalah data primer dan data sekunder Data primer diperoleh melalui wawancara, sedangkan data sekunder diperoleh diperpustakaan dan peneitian terdahulu. Teknik pengupulan data menggunakan observasi partisipatif, wawancara dan dokumentasi. Keabsahan data menggunkan triangulasi teknik dan triangulasi sumber. Teknik analisis data menggunakan pengumpulan data, reduksi data, penyajian data dan penarikan kesimpulan.

\section{HASIL DAN PEMBAHASAN}

\section{Hasil Penelitian \\ Jenis-Jenis Kesulitan Belajar}

Peserta didik mengalami kesulitan pada pembelajaran matematika dalam materi bangun datar persegi dan persegi panjang. Jenis-jenis kesulitan belajar matematika pada materi bangun persegi dan persegi panjang diantaranya kesulitan dalam memahami sifat-sifat bangun datar, kesulitan menentukan rumus, kelemahan menghitung, dan kesulitan bahasa serta membaca.

Peserta didik mengalami kesulitan dalam menentukan sifat-sifat bangun persegi dan persegi panjang. Kesulitan dalam menentukan sifat-sifat bangun persegi diantaranya peserta didik belum bisa menjawab dan keliru dalam mengerjakan soal tes. Hasil tes yang dikerjakan oleh informan 7, menuliskan bentuknya kotak pada soal sifat-sifat bangun persegi. Berdasarkan observasi informan 2 dan informan 3 tidak menuliskan jawaban pada soal sifat-sifat bangun persegi. Sedangkan informan 7 menjawab bentuknya kotak, bentuknya kotak tidak sesuai dengan sifat-sifat persegi, sehingga jawabanya kurang tepat. Berdasarkan hasil wawancara, pemahaman peserta didik masih sangat kurang. Hal tersebut sesuai yang disampaikan oleh Informan 2, "Ga tau bu, aku ga paham". Dari penjelasan tersebut diketahui bahwa infoman 2 belum memahami sifat-sifat yang dimiliki oleh persegi. Hal yang sama juga dikatakan oleh 
informan 7, "Ga tau bu, aku ga ngerti". Sedangkan menurut informan 1 selaku guru kelas IV, "Peserta didik sudah paham. Memiliki 4 sisi yang sama besar, 4 sudut yang sama besar, dan mereka membayangkannya dengan bentuk kotak.

Kesulitan peserta didik dalam memahami sifat-sifat bangun persegi panjang. Hasil tes kesulitan dalam memahami sifat-sifat bangun persegi panjang, yaitu peserta diidk tidak menuliskan jawaban dan menuliskan jawaban yang tidak sesuai. Informan 7 menuliskan "panjang" pada jawaban sifat-sifat persegi panjang. hasil observasi yang sudah dilakukan, informan 2, informan 3, dan informan 5 tidak menuliskan jawaban sifat-sifat persegi panjang. Hasil wawancara yang sudah dilakukan dapat diketahui bahwa pemahman peserta didik mengenai sifat-sifat bangun persegi panjang masih kurang. Sesuai yang disampaikan oleh Informan 3, "Tidak tahu bu, susah dipahami". Sedangkan informan 7, "Tidak tahu bu, aku ga ngerti sifat-sifat persegi panjang" Ketidaktahuan peserta didik dikarenakan peserta didik tidak paham dengan sifat-sifat yang dimiliki bangun persegi panjang.

Mempelajari bangun datar tidak lepas dari rumus yang digunakan ketika menjawab soal keliling dan luas dari bangun persegi dan persegi panjang. Berdasarkan hasil tes yang dikerjakan informan 5, tidak menuliskan rumus dalam menyelesaikan soal keliling persegi. Informan 3 tidak menuliskan rumus untuk menyelesaikan soal luas persegi. Hasil observasi yang sudah dilakukan diketahui beberapa peserta didik tidak menuliskan rumus ketika mengerjakan soal, hal ini disebabkan karena peserta didik kesulitan menentukan rumus untuk menyelesaikan suatu masalah. Informan 3, dan informan 5 tidak menuliskan rumus keliling persegi, namun langsung menuliskan angka untuk menyelesaikan soal tersebut. Berdasarkan hasil wawancara diketahui bahwa peserta didik tidak menuliskan rumus ketika mengerjakan soal. Hal ini didukung ketika peneliti menanyakan rumus keliling dan luas persegi, informan 3 mengatakan, "Tidak tahu bu, lupa. Soalnya waktu itu belajar bangun datarnya banyak jadi rumusnya banyak".

Selain kesulitan dalam menentukan rumus bangun persegi, peserta didik juga menglami kesulitan dalam menentukan rumus bangun persegi panjang. Hasil tes yang dikerjakan informan 4 kurang tepat dalam menuliskan rumus keliling persegi panjang, sedangkan informan 3 tidak menuliskan rumus luas persegi panjang untuk menyelesaikan soal. Hasil observasi peserta didik mengalami kesulitan didalam menentukan rumus keliling dan luas persegi. informan 3 tidak menuliskan rumus keliling dan luas persegi panjang, akan tetapi langsung memasukan angkanya dan menghitungnya untuk menyelesaikan soal. Sedangkan informan 4 kurang tepat didalam menuliskan rumus keliling persegi panjang, seharusnya keliling persegi panjang rumusnya adalah panjumlahan ruas garis / panjang sisi yang dimiliki oleh persegi (JK+KL+LM+MJ), namun yang ditulis adalah titik sudut $(\mathrm{J}+\mathrm{K}+\mathrm{L}+\mathrm{M})$, sehingga jawabannya kurang tepat. Hal ini didukung dengan hasil wawancara yang dilakukan peneliti bahwa peserta didik tidak mengetahui rumus keliling dan luas persegi panjang. Infoman 3, "Tidak tahu, aku ga inget semua rumusnya". Sedangkan informan 7 , "Ga tau rumusnya bu".

Pada saat menghitung peserta didik mengalami kesulitan dalam operasi hitung penjumlahan, perkalian dan pembagian dalam menyelesaikan soal yang berhubungan dengan keliling dan luas bangun persegi dan persegi panjang. Berdasarkan hasil tes yang dikerjakan oleh informan 3, mengalami kesulitan dalam melakukan operasi hitung penjumlahan. Dalam prosesnya sudah menuliskannya dengan baik, akan tetapi hasilnya salah, karena $6+8+6+8=$ 28 , bukan 48. Hal yang sama juga terjadi dalam operasi hitung perkalian, informan 5 tidak melakukan proses perhitungan dengan baik, tetapi hasil perhitungannya sudah benar, seharusnya ia menuliskan 6 × 6 agar hasilnya 36. Informan 4 melakukan kesalahan pada saat menghitung pembagian. Didalam proses menghitung sudah benar, akan tetapi salah dalam hasil akhirnya, seharusnya 24 dibagi 2 adalah 12, namun informan menuliskan 11.

Berdasarkan observasi, didalam menghitung peserta didik mengalami kesulitan baik didalam proses dan hasil perhitungannya. Informan 2 mengalami kesulitan pada operasi hitung pembagian, kurang teliti karena menghitungnya masih manual menggunkan jari sehingga hasilnya kurang tepat. Informan 2 menuliskan $50: 2=5$, seharusnya $50: 2=10$.

Kesulitan berhitung terjadi pada operasi hitung penjumlahan, perkalian dan pembagian sesuai dengan wawancara yang disampaikan oleh informan 7, "Sulit, aku ga bisa 
menghitungnya, ga tau caranya bu". Hal tersebut sesuai dengan yang disampaikan informan 1, "Kemampuan menghitungnya masih kurang. Kalau penjumlahan dan pengurangan mereka sudah bisa, kalau perkalian dan pembagian mereka belum bisa. Kebanyakan mereka belum bisa memahami proses dan cara menghitungnya sehingga hasil akhirnya salah".

Kesulitan dalam bahasa dan membaca erat kaitannya dengan soal yang disajikan dalam bentuk cerita. Berdasarkan hasil tes diketahui bahwa informan 3 kurang dapat memahami soal, sehingga tidak bisa menjawab maksud dari soal. Informan 5 kurang dapat memahami soal, sehingga tidak melanjutkan proses perhitungan untuk menyelesaikan soal. Informan 7 tidak dapat memahami soal dengan baik, sehingga didalam mengerjakan masih mengalami kesulitan. Berdasarkan observasi informan 3 tidak bisa menjawab maksud dari soal, tidak menuliskan rumus dan tidak melakukan perhitungan sehingga hanya menuliskan apa yang diketahui dan ditanyakan saja. Informan 7 tidak dapat memahami soal dengan baik dan mengalami kesulitan didalam mengerjakan soal, sudah benar dalam menuliskan apa yang diketahui, kurang tepat dalam menuliskan apa yang ditanyakan, seharusnya yang ditulis adalah luas bukan keliling, tidak menuliskan rumus, dan tidak menuliskan angka dengan benar, sehingga dalam melakukan perhitungan kurang tepat. Wawancara dengan informan 1, "Kemampuan dalam memahami soal cerita masih kurang, sehingga tidak bisa menyelesaikannya. Apalagi dirumusnya, soalnya saja belum paham maksudnya apa, mau dikalikan apa mau dibagikan kadang anak belum paham". Hal yang sama disampaikan informan 2, "Aku bacanya diulangi terus biar paham, bingung nentuin rumusnya". Kesulitan memahamami bahasa berkaitan dengan membaca dan operasi hitung, untuk menjawab soal cerita peserta didik harus membacanya berulang kali.

\section{Faktor-faktor Penyebab Kesulitan Belajar \\ Faktor Internal}

Faktor internal penyebab kesulitan belajar matemaika yaitu, kesehatan fisik dan sikap peserta didik dalam belajar. Kesehatan fisik berpengaruh besar dalam keberhasilan peserta didik saat mengerjakan soal. Berdasarkan observasi informan 5 meletakan kepalanya diatas meja. Reaksi tersebut menunjukan peserta didik merasa pusing. Hal tersebut membuatnya tidak mampu menyelesaikan soal dengan baik, dan melewati soal yang dianggap susah. Informan 2 mengantuk saat mengerjakan soal, sehingga melakukan kesalahan dalam menghitung. Berdasarkan wawancara dengan guru kelas IV, "Kalau anaknya lagi sakit, penginnya tiduran dikelas. Kalau mereka ngantuk, mereka cenderung tidak konsentrasi. Jika diberi tugas, ada yang mau mengerjakan ada yang tidak mau". Menurut informan 1 saat pembelajaran di kelas ketika ada peserta didik sakit, tiduran di kelas, yang dapat mengganggu konsentrasi dalam belajar, peserta didik tidak mau mengerjakan tugas yang diberikan oleh guru. Hal ini sesuai dengan wawancara informan 2, "Kalo aku sakit, aku ga memperhatiin guru". Informan 3, "Kalo aku lagi sakit aku ga memperhatiin guru, penginnya tiduran aja ga mau ngerjain nanti tambah sakit".

Sikap peserta didik dalam belajar dapat menimbulkan kesulitan belajar dan membuat hasil belajar rendah. Berdasarkan observasi informan 3, informan 4 dan informan 5 tidak bersemangat dan merasa pusing ketika mengerjakan soal. Wawancara dengan guru kelas IV, "Respon mereka kurang tertarik dengan pembelajaran matematika. Karena mereka mengalami kesulitan dalam menghitung jadi mereka kurang suka, dan kurang semangat belajar".

\section{Faktor Eksternal}

Faktor eksternal penyebab kesulitan belajar matematika meliputi guru dan alat yang digunakan dalam belajar. Guru dapat menyebabkan kesulitan belajar peserta didik. Berdasarkan hasil wawancara dengan guru kelas IV, "Saya selalu menerangkan dengan jelas agar dapat dipahami oleh anak, saya senyum, saya marah kalau ada anak yang bandel, tapi dinetralisisir supaya tidak menganggu yang lain. Saya memberi nilai tidak pelit, sesuai dengan usaha yang mereka lakukan”. Dari pernyatan tersebut guru pada saat memberikan penjelasan dan mengajar tersenyum dan tidak pelit ketika memberikan penilaian sesuai dengan usaha yang dilakukan oleh peserta didik. Hal tersebut berbeda dengan hasil wawancara dengan informan 2, "Gurunya tegas, ga senyum. Suasana kelas jadi ga tenang, belajarnya ga nyaman". Hal yang sama juga 
disampaikan oleh informan 6, "Gurunya tegas, galak, sering senyum, kalau ngasih nilai pelit soalnya nilainya aku kecil". Informan 7 mengatakan bahwa sikap guru ketika pembelajaran matematika tegas, galak, sering senyum dan saat membarikan nilai pelit karena mendapatkan nilai yang kecil.

Alat yang digunakan dalam pembelajaran dapat menunjang kegiatan belajar, sebaliknya jika guru dalam mengajar tidak menggunakan alat maka akan menyebabakan kesulitan belajar yang dialami peserta didik. Berdasarkan observasi yang dilakukan tidak ditemukan alat peraga bangun datar persegi dan persegi panjang, sehingga dalam pembelajaran anak mengalami kesulitan. Hal tersebut menjadikan guru untuk membuat alat peraga sendiri. Berdasarkan hasil wawancara dengan guru kelas IV, "Iya. Saya membuat alat peraga sendiri, pada materi bangun datar saya melibatkan anak dalam pembuatan alat peraga".

\section{Pembahasan}

\section{Jenis-jenis Kesulitan Belajar Matematika}

Peserta didik kelas IV mengalami kesulitan belajar matematika pada materi bangun datar persegi dan persegi panjang. Peserta didik mendapatkan nilai yang kurang baik dan tidak melanjutkan tugasnya dengan baik, karena mengalami kesulitan didalam menyelesaikan soal. Peserta didik dikatakan gagal apabila yang bersangkutan tidak dapat mengerjakan atau mencapai prestasi yang semestinya berdasarkan ukuran kemampuannya dalam mengerjakan [5]. Jenis-jenis kesulitan belajar matematika materi bangun persegi dan persegi panjang diantaranya kesulitan dalam memahami sifat-sifat bangun datar, kesulitan dalam menentukan rumus, kelemahan dalam menghitung, dan kesulitan bahasa serta membaca.

Kurangnya pengetahuan peserta didik mengenai sifat-sifat bangun datar dapat menyebabkan peserta didik mengalami kesulitan dalam memahami sifat-sifat bangun datar, khususnya pada bangun persegi dan persegi panjang. Kesulitan yang dialami peserta didik terlihat pada saat peserta didik mengerjakan soal tes yang diberikan oleh peneliti.

Kesulitan memahami sifat-sifat bangun persegi diantaranya peserta didik tidak bisa menjawab, dan kurang tepat dalam menjawab soal. Hasil tes peserta didik tidak menuliskan jawaban mengenai sifat-sifat persegi, padahal sudah mengetahui bentuk bangun persegi yang dapat dilihat pada soal mengenai nama bangun persegi. Akan tetapi belum bisa mengidentifikasi sifat-sifat persegi dari gambar yang dilihat. Dalam hal ini tidak sesuai dengan tahap perkembangan kognitif Piaget. Tahap progressive decentring, yaitu sebagian besar anak memiliki kemampuan untuk mempertahankan ingatan tentang panjang [6]. Peserta didik tidak dapat mengidentifikasi sisi-sisi persegi dari gambar persegi yang dilihatnya, dari gambar persegi dapat diketahui bahwa persegi mempunyai sisi yang sama panjang.

Kesulitan memahami sifat-sifat bangun persegi juga disebabkan karena peserta didik yang kurang tepat dalam menjawab. Hal ini diperjelas dengan jawaban hasil tes berikut.

$$
\text { Jawab: a perseg } 1 \text { b. bentul nya lootak }
$$

\section{Gambar 1. Jawaban kesulitan memahami sifat-sifat persegi}

Peserta didik menjawabnya dengan menuliskan bentuknya kotak, dengan demikian jawabannya tidak sesuai, karena bentuknya kotak bukan termasuk sifat-sifat yang dimiliki oleh bangun persegi. Walaupun bentuknya kotak memiliki emapt sisi, namun peserta didik belum menyebutkan sifat-sifat pesegi sesuai dengan teori, yaitu: a) mempunyai empat sisi yang sama panjang, b) sisi-sisi yang berhadapan sejajar, dan c) memiliki empat sudut siku-siku [7].

Selain mengalami kesulitan dalam memahami sifat-sifat bangun persegi, peserta didik mengalami kesulitan dalam memahami sifat-sifat bangun persegi panjang. Kesulitan tersebut diantaranya peserta didik tidak menjawab dan kurang spesifik dalam menuliskan jawaban.

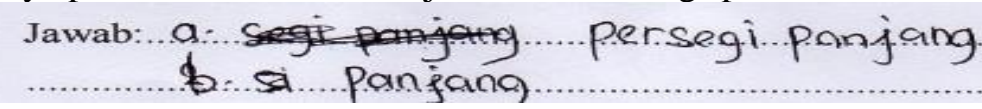

Gambar 2. Jawaban kesulitan dalam memahami sifat-sifat persegi panjang 
Peserta didik menuliskan panjang pada sifat-sifat persegi panjang. Hal ini bertolak belakang dengan sifat-sifat yang dimiliki oleh bangun persegi panjnag. Seharusnya peserta didik menjawab sifat-sifat persegi panjang adalah sisi-sisinya berhadapan sama panjang. Sesuai dengan teori sifat-sifat bangun persegi panjang diantaranya, a) sisi-sisi yang berhadapan sama sejajar dan panjang, dan b) memiliki empat [8]. Sesuai dengan pernyataan peserta didik ketika menjawab wawancara peneliti, dapat diketahui bahwa peserta didik belum bisa memahami sifatsifat bangun persegi panjang, namun peserta didik sudah paham ketika diberikan pertanyaan mengenai bentuk dari bangun persegi panjang.

Hal tersebut menjelaskan bahwa peserta didik kelas IV belum memahami sifat-sifat bangun persegi dan persegi panjang, dengan demikian peserta didik belum memahami konsep dari bangun persegi dan persegi panjang. Konsep menunjuk pada pemahaman dasar. Peserta didik mengembangkan suatu konsep ketika mereka mampu mengklasifikasikan/mengelompokan benda-benda atau ketika mereka dapat mengasosiasikan suatu nama dengan kelompok benda tertentu, sebagai contoh anak mengenal konsep persegi sebagai suatu bidang yang dikelilingi oleh empat garis lurus. Hal yang terjadi peserta didik mampu mengidentifikasi gambar bangun persegi dan persegi panjang, namun peserta didik belum bisa mengidentifikasi gambar sesuai dengan sifat-sifat persegi maupun persegi panjang [9].

Sebelum mengerjakan soal yang berkaitan dengan keliling dan luas dari bangun persegi dan persegi panjang, peserta didik hendaknya menuliskan rumus terlebih dahulu. Namun banyak peserta didik yang tidak menuliskan rumus ketika menjawab soal tes. Kesulitan tersebut dikarenakan kurangnya pemahaman peserta didik dalam memahami konsep dan sering salah menggunakan rumus dalam menyelesaikan soal [10]. Sesuai dengan hasil tes yang dikerjakan oleh peserta didik pada soal luas persegi. Peserta didik tidak menuliskan rumus luas persegi.

\section{Jawa $5+5+5+5 \quad 20 \mathrm{~cm}$}

\section{Gambar 3. Jawaban kesulitan mennetukan rumus keliling persegi}

Hasil tes peserta didik tidak menuliskan rumus keliling persegi. Namun dalam pengerjaan peserta didik langsung menuliskan angka " $5+5+5+5$ ". Dari hasil tes dapat diketahui peserta didik sudah mampu memahami konsep keliling persegi, bahwa keliling persegi adalah penjumlahan dari semua sisi persegi. Peserta didik sudah benar dalam proses pengerjaan soal. Hanya saja tidak menuliskan rumusnya sesuai dengan teori. Hal ini terlihat bahwa peserta didik sudah mampu menjumlahkan $5+5+5+5$, yang menunjukan bahwa persegi memiliki empat sisi. Rumus keliling persegi adalah 4 x s atau s x s x s x s [7]. Hal ini sesuai dengan hasil tes berikut.

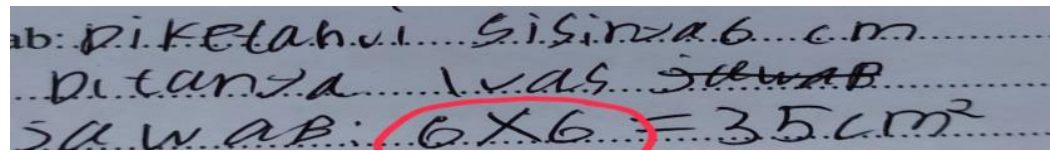

Gambar 4. Jawaban kesulitan menentukan rumus luas persegi

Peserta didik tidak menuliskan rumus luas persegi, namun langsung menuliskan angka dalam menyelesaikan soal. Peserta didik sudah mampu memahami konsep luas persegi, bahwa luas persegi adalah perkalian antar sisi persegi. Hasil tes peserta didik menuliskan " 6 x 6", menunjukan bahwa sisi dikali sisi. Peserta didik tahu bahwa $6 \mathrm{~cm}$ adalah besarnya sisi yang dimiliki persegi. Dalam hal ini peserta didik sudah memahami arti konsep luas, hanya saja peserta didik tidak menuliskan rumusnya secara konkrit. Rumus luas persegi adalah s x s [7]. 
Peserta didik yang tidak menuliskan rumus dalam mengerjakan soal, hal tersebut terjadi karena peserta didik lupa rumus keliling persegi.

Kesulitan menentukan rumus juga terjadi pada saat peserta didik mengerjakan soal keliling dan luas bangun persegi panjang. Peserta didik tidak menuliskan dan keliru dalam menuliskan rumus. Hal ini sesuai dengan hasil tes yang dikerjakan peserta didik.

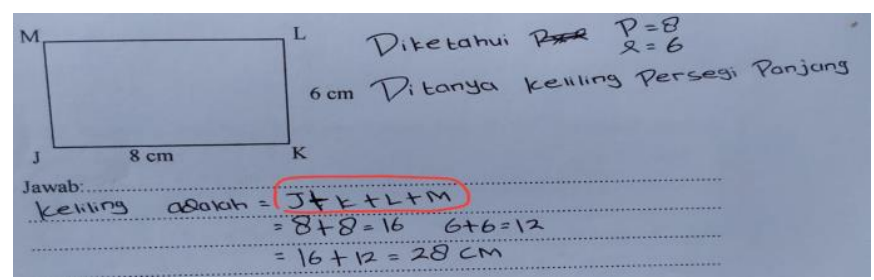

\section{Gambar 5. Jawaban kesulitan menentukan rumus keliling persegi panjang}

Peserta didik kurang tepat dalam menuliskan rumus keliling persegi panjang. Padahal peserta didik sudah mampu memahami konsep keliling persegi panjang, bahwa keliling persegi panjnag adalah penjumlahan dari sisi-sisi / panjang dan lebar yang dimiliki bangun persegi panjang. Hasil tes yang dikerjakan peserta didik menuliskan " $J+K+L+M$ ", hal ini tidak sesuai dengan rumus keliling persegi panjang. Rumus keliling persegi panjang adalah $2(\mathrm{p}+\mathrm{l})$ [8]. Kesulitan peserta didik dalam menentukan rumus terjadi karena cara belajar yang salah dan ceroboh dalam memahami soal, sehingga kurang tepat dalam menuliskan rumus serta menuliskan angka.

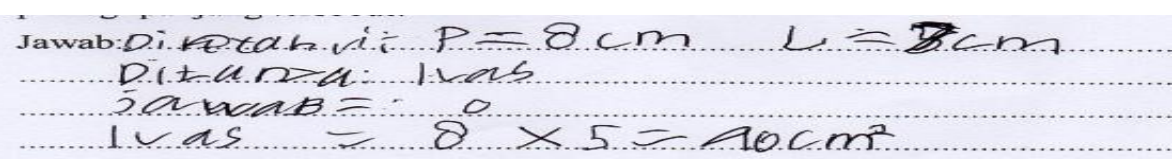

Gambar 6. Jawaban kesulitan menentukan rumus luas persegi panjang

Hasil tes yang dikerjakan peserta didik tidak menuliskan rumus luas persegi panjang, akan tetapi langsung menuliskan angka dan menghitungnya untuk menyelesaikan soal. Peserta didik sudah mampu memahami konsep luas persegi panjang. Bahwa luas persegi panjang adalah perkalian panjang dan lebar persegi panjang. Akan tetapi peserta didik tidak menuliskan rumus. Hal ini dituliskan pada jawaban peserta didik " 8 x 5", $8 \mathrm{~cm}$ adalah besarnya sisi panjang, dan 5 $\mathrm{cm}$ adalah besarnya sisi lebar yang dimiliki oleh persegi panjang. Rumus luas persegi panjang adalah p x 1 [8]. Dalam mengerjakan soal peserta didik tidak menuliskan rumusnya secara konkrit. Hal ini terjadi karena peserta didik lupa rumus, dan guru membiarkan peserta didik tidak menuliskan rumus.

Kesulitan peserta didik dalam menentukan rumus keliling dan luas dari bangun persegi dan persegi panjang diantaranya peserta didik tidak menuliskan rumus akan tetapi langsung menuliskan angka dan kurang tepat dalam menuliskan rumusnya. Penyebab kesulitan belajar adalah tidak hafal dengan rumus-rumus untuk menyelesaikan permasalahan sehingga terasa sulit bagi peserta didik [11]. Hal tersebut terjadi karena peserta didik lupa cara belajar peserta didik yang salah, kecerobohan dalam memahami soal, dan kebiasaan guru yang membiarkan peserta didik tidak menuliskan rumus saat mengerjakan soal.

Kelemahan dalam menghitung dapat mengakibatkan peserta didik mengalami kesulitan belajar matematika. Kesulitan tersebut terjadi dikarenakan peserta didik tidak teliti dalam melakukan operasi hitung. Matematika dianggap sebagai kegiatan yang dilakukan dengan menjumlahkan, mengurang, membagi atau kegiatan yang berkaitan dengan penyelesaian masalah hitungan yang disajikan dalam bentuk soal [12]. Menurut guru kelas IV, Kemampuan menghitung peserta didik masih kurang. Peserta didik sudah dapat melakukan operasi hitung penjumlahan dan pengurangan. Akan tetapi peserta didik mengalami kesulitan dalam operasi hitung perkalian dan pembagian. Pesrta didik mengalami kesulitan dalam memahami proses dan 
cara menghitungnya sehingga hasil akhirnya salah. Hasil tes yang dikerjakan peserta didik mengalami kesulitan dalam operasi hitung penjumlahan, perkalian dan pembagian. Berikut adalah kesulitan peserta didik dalam operasi hitung penjumlahan.

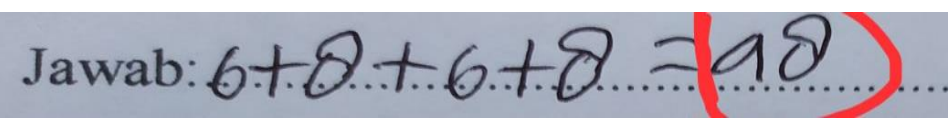

\section{Gambar 7. Jawaban kesulitan menghitung penjumlahan}

Peserta didik mengalami kesulitan dalam melakukan operasi hitung penjumlahan. Dalam proses pengerjaanya peserta didik sudah menuliskannya dengan baik, akan tetapi hasilnya kurang tepat karena $6+8+6+8=28$, bukan 48 . Hal ini terjadi karena peserta didik dalam menghitung tergesa-gesa dalam menyelesaikan soal sehingga tidak menuliskan kesimpulan jawaban sesuai dengan konteks soal. Hal yang sama terjadi dalam operasi hitung perkalian.

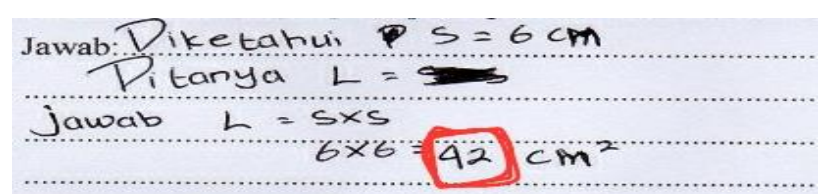

\section{Gambar 8. Jawaban kesulitan menghitung perkalian}

Peserta didik mengalami kesulitan dalam menghitung perkalian. Peserta didik kesulitan dalam hasil. Seharusnya yang dituliskan adalah $6 \times 6=36$, bukan 42 . Selain itu peserta didik mengalami kesulitan dalam operasi hitung pembagian, sebagai berikut.

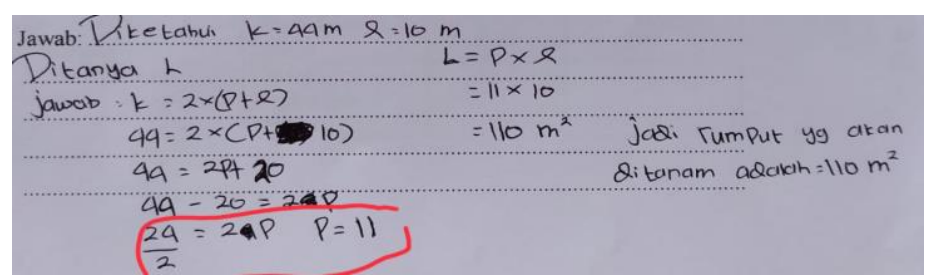

Gambar 9. Jawaban kesulitan menghitung pembagian

Peserta didik dalam menghitung mengalami kesulitan mengoperasikan pembagian. Didalam proses menghitung peserta didik sudah benar, akan tetapi salah dalam hasil akhirnya, seharusnya 24 dibagi 2 adalah 12, namun peserta didik menuliskan 11. Hal tersebut dikarenakan pada saat proses meghitung masih menggunakan jari secara manual.

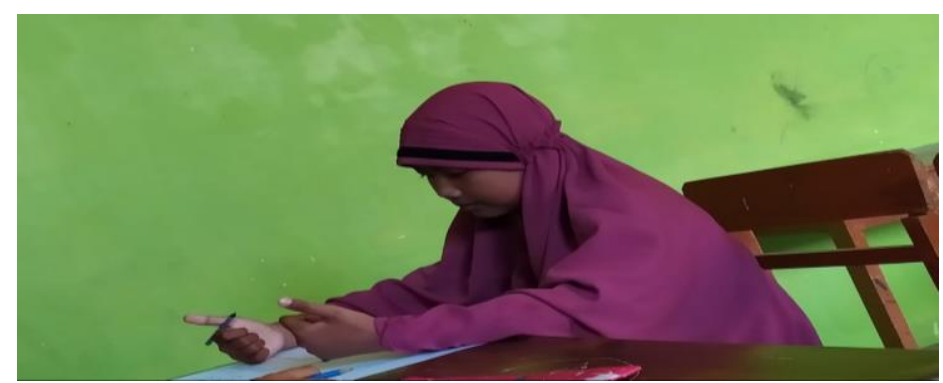

Gambar 10. Informan sedang menghitung dengan jari

Kesulitan dalam menghitung terjadi pada operasi hitung penjumlahan, perkalian dan pembagian. Hal tersebut karena peserta didik kurang latihan perhitungan dan kurang teliti dalam melakukan operasi hitung yang diminta [11]. Selain kurang teliti dalam menghitung, peserta didik belum memahami proses serta cara menghitungnya masih menggunakan jari secara manual, sehingga hasil akhirnya kurang tepat. 
Kesulitan bahasa dan membaca berkaitan erat dengan pemahaman soal cerita, namun pada saat belajar peserta didik mengalami kendala dalam menyelesaikan soal cerita. Kesulitan peserta didik dalam menyelesaikan soal yaitu kesulitan memahami maksud soal cerita [13]. Menurut guru kelas IV, Kemampuan dalam memahami soal cerita masih kurang, sehingga peserta didik tidak bisa menyelesaikannya. Pada bangun persegi dan persegi panjang banyak peserta didik yang tidak mengetahui rumusnya, belum paham maksudnya soal cerita yang ditanyakan, dan mengalami kesuitan dalam mengunkaan operasi hitung yang akan digunakan dalam menyelesaikan soal cerita. Hasil tes yang telah dikerjakan, peserta didik tidak dapat menjawab maksud dari soal, seperti pada gambar 11.

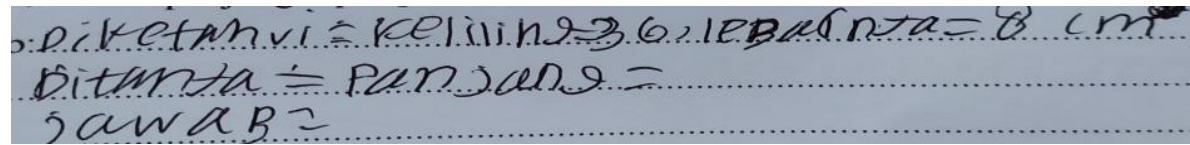

Gambar 11. Jawaban kesulitan bahasa dan membaca

Peserta didik mengalami kesulitan dalam memahami soal, peserta didik tidak bisa mengerti maksud dari soal, sehingga peserta didik tidak mengetahui langkah-langkah dalam menyelesaikan soal. Peserta didik seharusnya mencermati dengan saksama isi soal cerita. Jika diperlukan peserta didik mengambar terlebih dahulu gambar yang dimaksud dalam soal, kemudian tulislah apa yang diketahui dalam soal, dan pahami kembaali soal tersebut. Selain mengalami kebingungan dalam menentukan rumus, peserta didik juga tidak melanjutkan pengerjaannya untuk menyelesaikan soal. Hal ini sesuai dengan gambar 12.

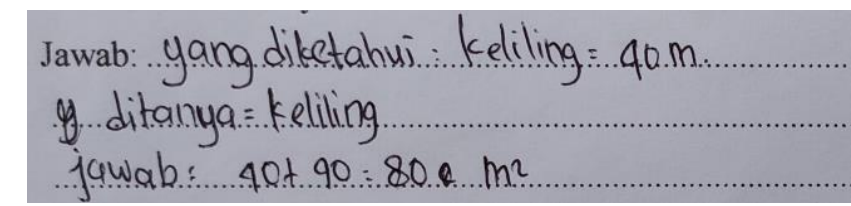

Gambar 12. Jawaban kesulitan bahasa dan membaca

Hasil tes yang dikerjakan oleh peserta didik kurang dapat memahami soal, sehingga tidak dapat merubah soal menjadi kalimat matematika. Sesuai dengan jawaban peserta didik, seharusnya yang ditanyakan adalah luas bukan keliling. Dalam menjawab peserta didik tidak menuliskan rumus, dengan demikian mengalami kesulitan dalam menyelesaikan soal. Hal ini terjadi karena dalam membaca soal peserta didik kurang cermat dalam memahaminya.

Kesulitan memahamami bahasa dan membaca, terjadi karena peserta didik kurang tepat dalam menggunakan rumus dan operasi hitung, peserta didik tidak melanjutkan langkah untuk menyelesikan soal, sehingga dalam menjawab soal cerita peserta didik harus membacanya berulang kali. Banyak peserta didik yang mengalami kesulitan dalam membuat hubunganhubungan yang bermakna matematika. Hal ini sering terjadi didalam memecahkan masalah yang berkaitan dengan hitungan soal yang disajikan dalam bentuk soal cerita [12]. Pemahaman soal cerita perlu diterjemahkan ke dalam operasi matematika yang bermakna. Permasalahan ini disebabkan oleh masalah yang berkaitan dengan kemampuan bahasa yang meliputi kemampuan membaca, menulis dan bertanya.

\section{Faktor-faktor Penyebab Kesulitan Belajar Matematika}

Kesulitan belajar pada materi bangun datar persegi dan persegi panjang dapat menyebabkan prestasi belajar peserta didik rendah. Kesulitan belajar peserta didik akan berdampak terhadap prestasi belajar peserta didik karena untuk memperoleh prestasi yang baik dapat diperlukan belajar di sekolah [10]. 


\section{Faktor internal}

Faktor internal penyebab kesulitan belajar matematika sangat berpengaruh terhadap kemampuan peserta didik dalam menyelesaikan soal matematika. Faktor internal adalah hal atau keadaan yang berasal dari dalam diri peserta didik [14]. Faktor internal tersebut meliputi kesehatan fisik dan sikap peserta didik dalam belajar. Masalah kesehatan yang sering terjadi pada saat proses belajar adalah kondisi fisik peserta didik yang kurang sehat. Kesehatan fisik sangat berpengaruh dalam belajar matematika, bahkan sampai menimbulkan kesulitan belajar matematika. Ketika peserta didik sakit dan mengantuk pada saat pembelajaran matematika, menandakan bahwa kesehatan fisik peserta didik terganggu. Peserta didik tidak berkonsentrasi dalam belajar, sehingga ketika guru sedang menjelaskan materi peserta didik tidak memperhatikannya. Peserta didik tidak dapat menyerap materi pelajaran dengan baik dan berdampak pada tertinggalnya materi pelajaran. Ketika peserta didik dalam kondisi fisiknya sakit dan tidak dapat berkonsentrasi dalam belajar, guru akan memanggil orang tuanya agar peserta didik dapat beristirahat di rumah.

Pada saat mengerjakan soal tes dijumpai peserta didik yang meletakan kepalanya diatas meja. Reaksi tersebut menunjukan bahwa peserta didik merasakan pusing dalam mengerjakan soal. Hal tersebut membuat peserta didik tidak mampu menyelesaikan soal dengan baik, dan melewati soal yang dianggapnya susah. Selain itu juga dijumpai peserta didik yang mengantuk pada saat mengerjakan soal tes, karena mengantuk peserta didik tidak berkonsentrasi dalam menghitung. Peserta didik menghitungnya dengan menggunakan jari secara manual, sehingga peserta didik tidak teliti, pada akhirnya hasil perhitungannya yang telah dikerjakan peserta didik kurang tepat.

Tingkat kebugaran jasmani mempengaruhi prestasi belajar peserta didik [13]. Kondisi fisik yang sehat dan bugar akan memberikan pengaruh positif terhadap kegiatan belajar individu. Sebaliknya kondisi fisik yang lemah akan menghambat tercapainya hasil belajar yang kurang maksimal. Untuk mengatasi mengatasi kesehatan pada peserta didik yang dapat membuatnya mengalami kesulitan dalam belajar matematika, guru dan orang tua harus bekerjasama dalam memberikan perhatian terutama dalam kesehatan fisik peserta didik. Peran guru dalam hal ini adalah guru dapat mengarahkan peserta didik untuk menjaga kesehatannya, sedangkan orang tua sebaiknya menjaga pola makan dan kesehatan anaknya sehingga kesehatan fisik dapat terjaga dengan baik, dengan demikian peserta didik dapat menyerap dengan baik pula materi matematika yang dijelaskan oleh guru.

Dalam proses belajar matematika sangat menyenangkan apabila dalam belajar peserta didik menyukainya. Akan tetapi ada saatnya peserta didik tidak menyukainya dikarenakan peserta didik merasa bingung dan pusing dalam belajar matematika. Sikap peserta didik tersebut dapat mempengaruhi dalam proses belajar dan membuatnya mengalami kesulitan belajar matematika, sehingga hasil belajar peserta didik kurang maksimal. Pada saat mengerjakan soal tes yang diberikan oleh peneliti, sebagian besar peserta didik tidak menyukai matematika. Hal ini disebabkan karena peserta didik mengalami kesulitan dalam berhitung, sehingga merasa pusing dan tidak bersemangat dalam mengerjakan soal. Sikap peserta didik dalam belajar dapat dipengaruhi oleh perasaan senang atau tidak senang terhadap performan guru, pelajaran atau lingkungan sekitarnya [9].

\section{Faktor eksternal}

Faktor eksternal penyebab kesulitan belajar matematika sangat berpengaruh terhadap kemampuan peserta didik dalam menyelesaikan soal matematika. Faktor eksternal adalah hal atau keadaan yang berasal dari luar diri peserta didik [14] Faktor eksternal meliputi guru dan alat yang digunakan dalam belajar. Guru merupakan salah satu komponen utama dalam proses pembelajaran di sekolah. Guru tidak hanya menyampaikan informasi dengan mengajar, akan tetapi guru juga harus mempunyai sikap yang baik terhadap pseserta didiknya. Sikap guru dapat menyebabkan kesulitan belajar bagi peserta didik. Dalam hal ini guru harus dapat menjaga hubungan baik dengan peserta didik, sehingga dalam kegiatan belajar mengajar berlangsung 
dengan baik. Guru dan cara mengajarnya merupakan faktor terpenting dalam menentukan keberhasilan anak dalam belajar [9].

Sikap guru yang suka marah ketika ada salah satu peserta didik yang bandel, dapat mengakibatkan suasana kelas khusunya untuk belajar matematika tidak nyaman, dan sikap guru tersebut cenderung membuat peserta didik merasa ketakutan dalam belajar. Selain itu guru dalam memberikan nilai kecil, walaupun guru dalam standar penilaian sesuai dengan proses yang dilakukan oleh peserta didik. Nilai peserta didik kecil dapat membuatnya tidak bersemangat dalam belajar sehingga menimbulkan kesulitan belajar. Guru dapat menjadi penyebab kesulitan belajar karena pengambilan metode yang digunakan kurang sesuai, sifat, sikap guru yang tidak disenangi peserta didik, seperti (a) guru suka marah, tidak pernah senyum, (b) tidak pandai menerangkan, (c) pelit dalam memberikan angka, dan (e) metode mengajar guru yang dapat menimbulkan kesulitan belajar [15].

Guru menyadari pentingnya alat yang digunakan dalam pembelajaran. Alat sebagai media penyampaian informasi agar peserta didik lebih mudah dalam memahami materi yang diajarkan oleh guru, dengan demikian adanya alat dapat menunjang kegiatan belajar, sebaliknya jika guru dalam mengajar tidak menggunakan alat peraga, maka akan menyebabakan kesulitan belajar yang dialami peserta didik. Berdasarkan penuturan guru, tidak ditemukan alat peraga bangun datar persegi dan persegi panjang, sehingga dalam pembelajaran anak mengalami kesulitan. Alat pelajaran yang kurang lengkap menyebabkan penyajian pelajaran yang tidak baik [15]. Terutama dalam pembelajaran matematika. Alat peraga yang digunakan pada materi bangun datar persegi dan persegi panjang, guru membuatnya sendiri dengan melibatkan peserta didik dalam pembuatannya.

\section{SIMPULAN}

Berdasarkan hasil penelitian dan pembahasan analisis kesulitan belajar muatan matematika kelas IV SD Tahfidzul Qur'an Darul Abror diperoleh kesimpulan diantaranya, jenis-jenis kesulitan belajar matematika yang dialami peserta didik pada materi bangun datar persegi dan persegi yaitu peserta didik kesulitan memahami sifat-sifat bangun datar, kesulitan menentukan rumus untuk menyelesaikan masalah, kelemahan dalam menghitung dan kesulitan bahasa dan membaca. Faktor penyebab kesulitan belajar matematika terdiri dari faktor internal dan faktor eksternal. Faktor internal adalah faktor yang berasal dari dalam diri peserta didik meliputi keshatan fisik dan sikap peserta didik dalam mengikuti pembelajaran matematika. Faktor eksternal adalah faktor yang berasal dari luar diri peserta didik meliputi guru, dan alat yang digunakan dalam pembelajaran.

\section{REFERENCES}

[1] Susanto, Ahmad., Teori Belajar dan Pembelajaran di Sekolah Dasar, 2013, Kencana, Jakarta.

[2] Waskitoningtyas, Rahayu Sri., "Analisis Kesulitan Belajar Matematika Siswa Kelas V Sekolah Dasar Kota Balikpapan Pada Materi Satuan Waktu Tahun Ajaran 2015/2016”, Jurnal Ilmiah Pendidikan Matematika, vol. 5, no. 1, [Online]. Available: $\underline{\text { http://e- }}$ journal.unipma.ac.id/index.php/jipm/article/view/852.

[3] Astuti, Fitri Novi., Analisis Kesulitan Pemahaman Konseptual Siswa Dalam Menyelesaikan Soal Pada Materi Peluang Di MAN Sanggau, Jurnal Pendidikan Dan Pembelajaran Khatilistiwa, vol. IV, no. 10, [Online]. Available: http://jurnal.untan.ac.id/index.php/jpdpb/article/view/11971.

[4] Nurdiantoro, Faisal., Kesulitan Belajar Matematika Peserta Didik Kelas IV SD Negeri 3 Rejoagung Kedunwaru Tulungagung, Skipsi, IAIN Tulungagung. Program Studi Pendidikan Guru Madrasah Ibtidaiyah, 2017, Tulungagung.

[5]Widyasari, Ni Made Dwi., Analisis Kesulitan Belajar Matematika Siswa Kelas IV Dalam Implementasi Kurikulum 2013 Di SD Piloting Se-Kabupaten Gianjar, e-Jurnal PGSD, vol. III, no. 1, [Online]. Available: https://ejournal.undiksha.ac.id/index.php/JJPGSD/article/view/5069.

[6] Mu'min, Siti Aisyah., "Teori Perkembangan Jean Piaget”, Jurnal Al-Ta'dib, vol.6, no. 1, [Online]. Available: https://media.neliti.com/media/publications/235758-teori-perkembangan-kognitif-jeanpiaget-48cba26e.pdf. 
[7] Hasanah, Analisis Kesulitan Belajar Siswa Ditinjau Dari Segi Kemampuan Koneksi Matematika Materi Pokok Segiempat Dan Segitiga Pada Siswa Kelas VII MTs Yusuf Abdussatar Tahun Ajaran 2016/2017, Skripsi, Fakultas Ilmu Trabiyah Dan Keguruan, Universitas Islam Negeri Mataram, 2017, Mataram.

[8] Nelawati, Pengembangan Modul Materi Bangun Datar Siswa SD Bercirikan Etnomatematika Di Kabupaten Oku Timur, Skripsi, Fakultas Tarbiyah Ilmu Dan Keguruan, Universitas Islam Negeri Raden Intan, 2018, Lampung.

[9] Tyas, Ni'mah Mulyaning, Analisis Faktor Penyebab Kesulitan Belajar Matematika Kelas IV Sekolah Dasar Negeri di Kecamatan ungaran Barat Kabupaten Semarang, Skripsi, Fakultas Ilmu Pendidikan, Universitas Negeri Semarang. Program Studi Pendidikan Guru Sekolah Dasar, 2016, Semarang.

[10] Jamal, Fakhrul., “Analisis Kesulitan Belajar Siswa Dalam Mata Pelajaran Matematika Pada Materi Peluang Kelas XI IPA SMA Muhammadiyah Meulaboh Johan Pahlawan, Jurnal Pendidikan Matematika, vol. $1, \quad$ no. $1, \quad$ [Online]. Available: https://ejournal.stkipbbm.ac.id/index.php/mtk/article/view/232.

[11] Cahyaningrum, Siti., "Identifikasi Kesulitan Dalam Menyelesaikan Soal Cerita Pokok Bahasan Prisma Dan Limas Siswa Kelas VIII Semester II SMP Negeri Delanggu Tahun Ajaran 2014/2015”, Naskah Publikasi, [Online]. Available: http://eprints.ums.ac.id/38359/.

[12] Utari, Rizky Dian., "Analisis Kesulitan Belajar Matematika Dalam Mentelesaikan Soal Cerita", Jurnal Ilmiah Sekolah Dasar, vol. 3, no. 4, pp. 534-540, [Online]. Available: http://ejournal.undisha.ac.id/index.php/JISD/index.

[13] Supriyanto, Analisis Kesulitan Belajar Matematika Siswa Dalam Pembelajaran Sejarah, Jurnal Swarnadwipa, vol. II, no. 1, [Online]. Available: https://ojs.ummetro.ac.id/index.php/swarnadwipa/article/view/759.

[14] Jamaris, Martini., Kesulitan Belajar Bagi Anak Usia Dini dan Usia Sekolah, 2015, Ghalia Indonesia, Bogor.

[15] Hasibuan, Eka Khairani., Analisis Kesulitan Belajar Matematika Siswa Pada Pokok Bahasan Bangun Ruang Sisi Datar Di SMP Negeri 12 Bandung, AXIOM, vol. VII, no. 1, [Online]. Available: http://jurnal.uinsu.ac.id/index.php/axiom/article/view/1766. 